\title{
Guided reflection as a tool to deal with the theory- practice gap in critical care nursing students
}

\begin{abstract}
Authors:
Hester Cathrina de Swardt (Rina) $)^{1,2}$

Heleen S. du Toit ${ }^{2}$

Annali Botha ${ }^{2}$

Affiliations:

${ }^{1}$ Adelaide Tambo School of

Nursing Science, South Africa

${ }^{2}$ Department of Health

Studies, University of

South Africa, South Africa

Corresponding author:

Hester de Swardt (Rina)

Email:

deswardtr@tut.ac.za

Postal address:

Private Bag X680,

Pretoria 0001, South Africa

Dates:

Received: 23 Feb. 2011

Accepted: 06 Dec. 2011

Published: 13 Apr. 2012

How to cite this article: De Swardt, H.C., Du Toit, H.S. \& Botha, A., 2012

'Guided reflection as a tool to deal with the theorypractice gap in critical care nursing students', Health SA Gesondheid 17(1), Art. \#591, 9 pages. http://dx.doi. org/10.4102/hsag.v17i1.591
\end{abstract}

(C) 2012. The Authors. Licensee: AOSIS OpenJournals. This work is licensed under the Creative Commons Attribution License.
Critical care nursing students experience inconsistencies between the theoretical content they have learnt and what is expected from them in practice, which retards the learning process. This has been described as the theory-practice gap. There seems to be no single solution to address the integration of theory and practice. In an attempt to bridge this gap, a study was done to establish the influence of guided reflection on critical care nursing students in dealing with their theoretical and practical experiences. A qualitative, explorative, descriptive and contextual design was followed. An instrument for guided reflection was designed which was used during semi-structured interviews during the data collection process. Field notes and narrative descriptions were also used as means to collect data. Themes that emerged from the data included a description of incidents experienced, critical analysis of knowledge, critical analysis of feelings and changed perspective experienced. Theory-practice integration occurred to an extent in some of the categories; conversely, the inability to apply theory to practice evoked responses such as feelings of guilt and incompetence. Guided reflection appeared to have assisted the participants in clarifying theoretical and practical experiences, and in reaching a changed perspective by understanding the link between theory and practice. Guided reflection ought to be incorporated in the education of nurses from their basic training in theory and practice so that student nurses will be aware of their own competencies in order to provide optimal patient care.

Kritiekesorgverpleegstudente ervaar teenstrydighede ten opsigte van dit wat hul geleer word en wat van hul in die praktyk verwag word wat weer die leerproses vertraag. Dit word as die teorie-praktykgaping beskryf. Daar blyk geen enkelvoudige oplossing te wees vir die integrasie van teorie en praktyk nie. In 'n poging om die gaping te oorbrug, is 'n studie oor die invloed van begeleide refleksie op kritiekesorgverpleegkundige studente se teoretiese en praktiese ervaringe gedoen. 'n Kwalitatiewe, verkennende, beskrywende en kontekstuele navorsingsontwerp is gevolg. ' $n$ Instrument vir begeleide refleksie is ontwerp wat gebruik is tydens semi-gestruktureerde onderhoude in die data-insamelingsproses. Veldnotas en narratiewe beskrywings was ook middele ten einde data in te samel. Tema's wat uit die data na vore gekom het was 'n beskrywing van ervaringe, kritiese analise van data, kritiese analise van gevoelens en ' $n$ veranderde perspektief met betrekking tot ervaringe. Teorie-praktyk integrasie het tot ' $n$ mate in sommige kategorieë plaasgevind het. Daarinteen het die onvermoë om die teorie in die praktyk toe te pas response tot gevolg gehad, soos skuldgevoelens en gevoelens van onbevoegdheid. Dit wil voorkom asof begeleide refleksie die deelnemers gehelp het om duidelikheid en 'n veranderde perspektief ten opsigte van hul teoretiese en praktiese ervaringe te verkry. Begeleide refleksie behoort reeds vanaf basiese opleiding in verpleegkundiges se teoretiese en praktiese opleiding geïnkorporeer te word sodat verpleegkundiges bewus sal wees van hulle eie vaardighede om sodoende optimale pasiëntsorg te kan lewer.

\section{Introduction}

Despite widespread agreement that the theory-practice gap is a reality in nursing education, Gallagher (2004:267) is of the opinion that the term is so embedded in educational nurse literature that it is very often used mindlessly and as a 'thought stopper'. Rafferty, Allcock and Lathlean (1996:689), however, conclude that the debate surrounding the theory-practice gap is not only inevitable and healthy but also necessary for change in education. The theory-practice gap has been studied widely in nursing in an attempt to integrate theory with practice (Baxter 2007:104; Maben, Latter \& Macleod Clark 2006:473).

Although the literature describes the influence of factors such as role models, the sequence in which theory and practice are organised, the learning environment and teaching and learning 
strategies, inadequate theory and practice integration still occurs; this results in the theory-practice gap. Mabuda, Potgieter and Alberts (2008:23) confirm the theory-practice gap as being a hindrance in student nurses' learning process. Inadequate theory-practice integration is reflected in areas such as medication errors and incompetent nursing care and nursing-care decisions (Gregory, Guse, Davidson, Davis \& Russell 2009:23; Jones \& Treiber 2010:240).

The integration of theory and practice is, however, a multifactorial problem of which role models and the curriculum are only two factors impacting on it (Landers 2000:1554). Role models, such as the professional nurse as practitioner, clinical facilitator, nurse educator, mentor and preceptor, may either support or impede the learning and practice of student nurses (Clark \& Holmes 2007:1211; Maben et al. 2006:475; Sedgwick \& Yonge 2008:624).

The curriculum is concerned with how, when, and where the application of theory is implemented in practice (Morgan 2006:160). A well-designed curriculum that includes theory and practice prepares student nurses to become competent practitioners (Lerners \& Piccone 2006:505). Student nurses are socialised by both learning and practice environments, which subsequently influences their theory-practice integration. This is explained as the influence of the 'hidden curriculum' - the unintended learning that shapes students' attitudes, values, beliefs and associated behaviour (Jones, Hanson \& Longacre 2004:265). Because of the formal and the hidden curricula, student nurses learn intentionally and unintentionally. These learning experiences may influence their practice favourably or unfavourably.

In addition, specific teaching and learning strategies are suggested to promote the integration of theory and practice. The strategies include evidence-based practice, computerbased support, case studies and reflective practice (Billings \& Kowalski 2006:248; Botha 2006:324; Gallagher 2004:266; Malesela 2009). Reflective practice has not been used as a strategy in the learning environment where the researcher was involved in the training of critical care nurses.

\section{Problem statement}

The researcher observed this theory-practice gap as clinical facilitator of critical care nursing students; for example, the critical care nursing students were taught the concept cardiac output, but when asked to relate this concept to the patient being cared for, they were unable to apply it. Clinical manifestations of the patient indicating a low cardiac output could not be recognised. This may have serious consequences as it implies that these critical care nursing students' interventions or decisions might be informed by trial and error and not sound scientific principles, and this may result in inappropriate nursing interventions with possible negative consequences for the patient.

This article aims to describe the use of guided reflection as a teaching and learning strategy to deal with the theoretical and practical experiences of critical care nursing students. The rationale for using guided reflection was that, although described in the research literature, it was not being used in the clinical teaching environment in which the researcher worked.

\section{Research question and objectives}

The question informing this research was: how would guided reflection influence second-year critical care nursing students' experience of theory-practice integration in a private hospital in Gauteng?

The objectives of this study were to:

- facilitate guided reflection in critical care nursing students

- describe the experiences of critical care nursing students when guided reflection was applied to theory-practice integration.

\section{Guided reflection}

The concept of learning from reflecting on practical experiences was pioneered by Dewey in 1933 (Foster \& Greenwood 1998:166). Reflective practice could be described as a deliberate cognitive and affective exploration of experiences with the purpose to learn from experiences (Chapman, Dempsey \& Warren-Forward 2009:167). Different methods can be used to reflect, for example, reflective diaries or journals, reflective group discussions and guided reflection. Guided reflection is a form of reflection which occurs between facilitators and practitioners or students in a structured way. In this research, guided reflection was used as a method to facilitate theoretical and practical experiences of critical care nursing students. The reason for guiding the reflective process is that it is difficult for novices, in this case critical care nursing students to reflect on their learning experiences without guidance (Duffy 2008:335).

Before commencing the process of reflection, awareness of certain prerequisites and barriers are needed. An attitude of openness, flexibility and a sincere intent to reflect is essential. The person with whom the reflection is shared should be trustworthy and approachable. The barriers in the process of reflection are time constraints, possible anxieties the student may experience due to painful previous encounters and possible ethical issues that might be revealed (Duffy 2009:170). In this study, the researcher facilitated guided reflection-on-action, meaning that the reflection took place retrospectively, on one nursing care incident chosen by each of the participants. As suggested by Foster and Greenwood (1998:169), the researcher needed to give up her position of authority as clinical facilitator during this process of reflection to ensure that meaningful reflection could occur. A non-threatening relationship was important.

Johns' (1995:227) model for reflection was used as a basis to design an instrument for guided reflection. The patterns of knowing - aesthetics, personal ethics, empirics and reflexivity - served as the key concepts. Open-ended questions were asked to guide the reflective process. 


\section{Research significance}

Through exploring and describing the theoretical and practical experiences of critical care nursing students using guided reflection, competencies such as critical thinking skills, self-empowerment, creativity, ownership of learning outcomes and dealing with ethical issues, were enhanced. An awareness of the influence of feelings during decisions regarding patient care became apparent. These competencies may influence optimal patient care.

\section{Research design and method Design}

A qualitative, explorative, descriptive and contextual research approach was followed to capture the experiences of second-year critical care nursing students that participated in guided reflection. The purpose of exploratory research is to investigate a phenomenon about which little is known and to understand its dimensions (Schmidt \& Brown 2009:149). The descriptive nature of this study was achieved by giving a detailed description of the phenomenon of guided reflection applied to the study context where the researcher attempted to address the theory-practice gap of critical care nursing students. As Gray (2009:35) suggests, such attention to detail creates a picture of what naturally occurred. Burns and Grove (2005:52) state that the context of where it occurs is important to understand the meaning of human experiences. The context was a critical care unit in a private hospital in Gauteng. Critical care nursing students worked in this unit to fulfil the practical requirements of their critical care nursing qualification.

\section{Population and sampling}

The target and accessible population for this study was secondyear critical care nursing students who were employed by a private hospital in Gauteng, and who were registered for a critical care nursing course at a university. The reason for targeting this specific population was that, in terms of the structure of the course, critical care nursing specialisation was the focus in the second year. It therefore meant that the participants would be able to provide information detailing the typical experiences of critical care nursing students when implementing theory in practice. Only seven persons met the criteria and all of them were approached to form part of this study whilst adhering to ethical principles.

\section{Research procedure and data collection}

The steps in the research and data-collection process were as follows:

- The researcher acted as a facilitator to guide the reflectionon-action in terms of a critical incident. Each participant was required to select a critical incident that he or she considered to be complex, unusual and occurred whilst caring for a critically ill patient.

- A designed instrument for guided reflection served as a data-collection instrument and also assisted the researcher to a guide the process of guided reflection as a semistructured interview. The participants were individually guided to reflect on their unique theoretical and practical experiences related to the incident. The process occurred in a quiet environment where the participants could reflect without any distractions, and took an average of one hour per participant. The verbatim data were taperecorded and transcribed at a later stage.

- Written narratives were composed by each participant directly after the guided reflection had been facilitated. The narratives contained data on how they experienced the facilitated guided reflection and how this experience might impact on their application of theory in practice in the future. Written narratives are commonly used in qualitative research and can be obtained either through diaries or written descriptions (Streubert Speziale \& Carpenter 2007:25).

- The researcher also reflected by keeping personal and observational notes after the interviews on aspects such as non-verbal communicative elements, as well as on the reflective process as a whole. As Streubert Speziale and Carpenter (2007:43) suggest these could be regarded as field notes to be used as reference when the transcribed data and narratives were analysed.

\section{Data analysis}

The purpose of qualitative data-analysis is to create order, structure and meaning from a large amount of information (De Vos, Strydom, Fouché \& Delport 2005:333). The verbatim transcripts of the guided reflective interviews and narrative descriptions were read and re-read to identify the underlying meaning of the information. During open-coding, data were grouped together into major themes, categories and subcategories. The data were set aside for a period of time and recoded to enhance trustworthiness. The main themes that emerged were (Table 1):

- description of incidents experienced

- critical analysis of knowledge

- critical analysis of feelings

- changed perspective experienced.

The categories and subcategories belonging to each theme are tabulated.

Axial coding followed as described by De Vos et al. (2005:341) as a process following open coding during which data is put back together in a new way illustrating connections between categories. This was done and data were arranged in a conceptual framework (Figure 1).

\section{Ethical considerations}

Ethical considerations that were taken into account included human rights, that is, the right to self-determination, privacy, anonymity, confidentiality and fair treatment. Approval to conduct the study was obtained from participants, hospital management and the Senate of the University of South Africa, which served as an ethics approval body at the stage that the study was conducted. Participation was voluntary and each participant signed an informed consent and could withdraw at any time during the study. The privacy, anonymity and 
TABLE 1: Overview of the themes, categories and subcategories.

\begin{tabular}{|c|c|c|}
\hline Themes & Category & Subcategory \\
\hline \multirow[t]{7}{*}{ Description of incidents experienced } & Patient data & $\begin{array}{l}\text { - Assessments findings } \\
\text { - Critical assessment findings }\end{array}$ \\
\hline & Doctor action & $\begin{array}{l}\text { - Medical diagnoses } \\
\text { - Life-saving actions } \\
\text { Routine actions }\end{array}$ \\
\hline & Nurse action & $\begin{array}{l}\text { - Routine action } \\
\text { - Life-saving action }\end{array}$ \\
\hline & Treatment & $\begin{array}{l}\text { - Family communication } \\
\text { - Patient communication }\end{array}$ \\
\hline & Communication & $\begin{array}{l}\text { - Family communication } \\
\text { - Patient communication }\end{array}$ \\
\hline & Experience & - Experience \\
\hline & Outcome & - Outcome \\
\hline \multirow[t]{8}{*}{ Critical analysis of knowledge } & Knowledge & $\begin{array}{l}\text { - Lack of knowledge } \\
\text { - The need to update knowledge }\end{array}$ \\
\hline & Doctor/nurse action & $\begin{array}{l}\text { - Motivation for actions } \\
\text { - Life-saving actions } \\
\text { - Questioning actions } \\
\text { - Consequences of actions } \\
\text { - Exclusive doctor action }\end{array}$ \\
\hline & Medication & $\begin{array}{l}\text { - Life-saving medication } \\
\text { - Questioning medication }\end{array}$ \\
\hline & Theory-practice integration & - Application of theory to practice \\
\hline & Outcome & - Patient outcome \\
\hline & Experience & $\begin{array}{l}\text { - Previous experience } \\
\text { - First experience }\end{array}$ \\
\hline & Student reasoning & - Student reasoning \\
\hline & Malfunctioning of equipment & - Malfunctioning of equipment \\
\hline \multirow[t]{2}{*}{ Critical analysis of feelings } & Experience & $\begin{array}{l}\text { - Unpleasant / traumatic experience versus ordinary } \\
\text { experience } \\
\text { - Overwhelming experience }\end{array}$ \\
\hline & Expression of feelings & $\begin{array}{l}\text { - Feelings of confusion and frustration } \\
\text { - Feelings of incompetence } \\
\text { - Feelings of loss } \\
\text { - Feelings of denial } \\
\text { - Feelings of guilt } \\
\text { - Feelings of anger } \\
\text { - Feelings of acceptance/non-acceptance } \\
\text { - Feelings towards colleagues } \\
\text { - Feelings concerning discrepancies }\end{array}$ \\
\hline \multirow[t]{7}{*}{ Changed perspective experienced } & Outcome of action & $\begin{array}{l}\text { - Life-saving action } \\
\text { - Death }\end{array}$ \\
\hline & View of doctor/nurse action & $\begin{array}{l}\text { - Agree/Disagree } \\
\text { - Diagnosis } \\
\text { - Emergency treatment } \\
\text { - Suggestion about treatment }\end{array}$ \\
\hline & Participants' view of theory-practice integration & - Theory-practice integration \\
\hline & Knowledge & $\begin{array}{l}\text { - Responsibility for own learning } \\
\text { - Subject-specific knowledge } \\
\text { - The effect of knowledge }\end{array}$ \\
\hline & Feelings & $\begin{array}{l}\text { - Stress feelings } \\
\text { - Feelings of guilt } \\
\text { - Conflicting feelings } \\
\text { - Feelings of acceptance } \\
\text { - Positive feelings }\end{array}$ \\
\hline & Reporting & $\begin{array}{l}\text { - Staff-related reporting } \\
\text { - Patient-related reporting }\end{array}$ \\
\hline & Education & $\begin{array}{l}\text { - In-service training } \\
\text { - Practical placement } \\
\text { - Mentors } \\
\text { - Time constraints } \\
\text { - Teaching method }\end{array}$ \\
\hline
\end{tabular}

confidentiality of the participants were protected by not linking any names or the name of the institution to the collected data.

\section{Trustworthiness}

Measures to ensure trustworthiness were applied based on the model proposed by Lincoln and Guba (1985:290), and included credibility, transferability, dependability and confirmability. Different strategies were applied to enhance the trustworthiness of this study as summarised in Table 2.

\section{Discussion of results}

The results are presented in terms of the four main themes (Table 1), namely description of incidents experience, critical analysis of knowledge, critical analysis of feelings, and changed perspective experienced.

\section{Theme 1: Description of incidents experienced}

In this theme the participants mainly described incidents they had experienced; for example, patient data, doctor action, nurse action, treatment, communication, experience 


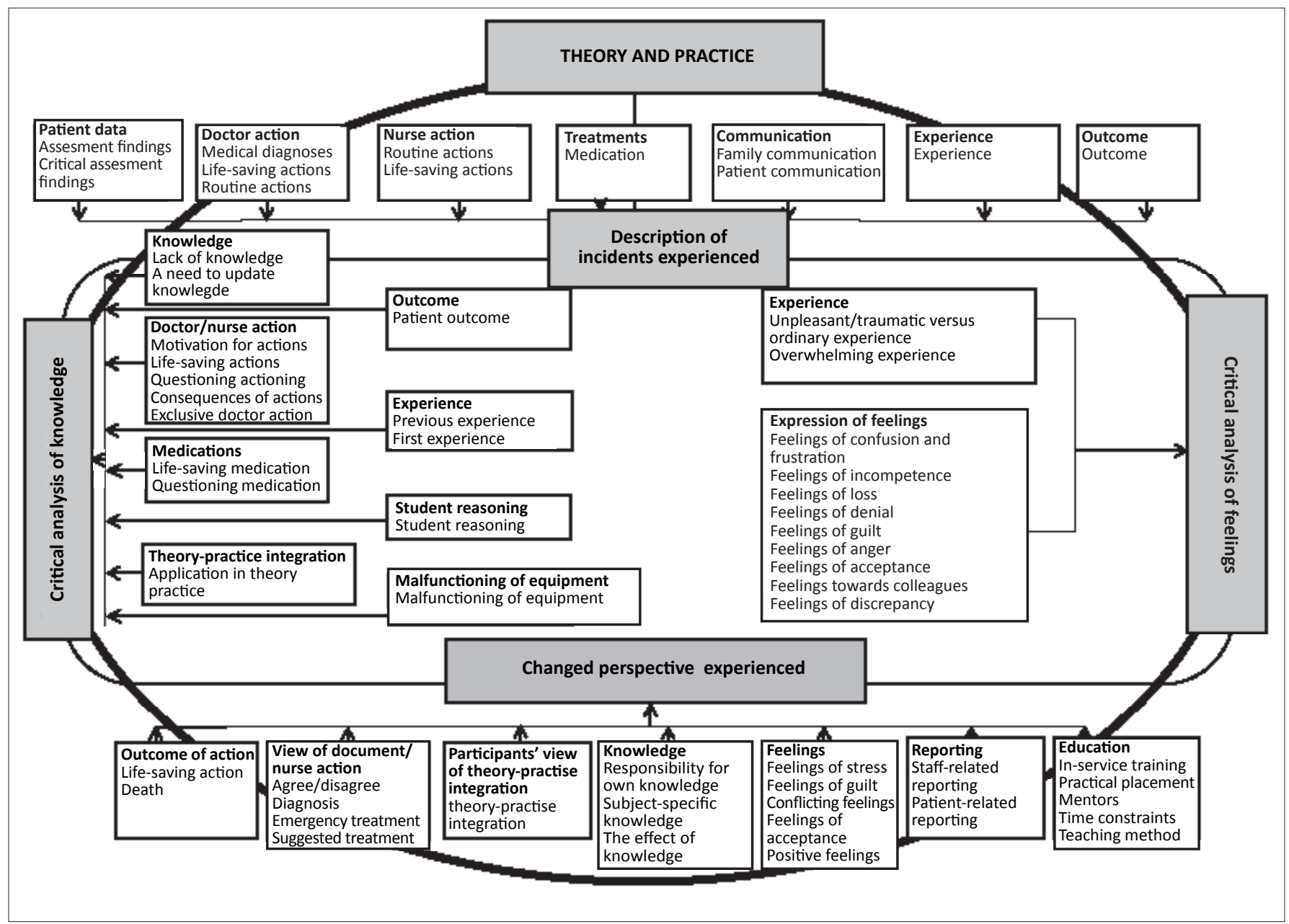

FIGURE 1: An overview of the themes, categories and subcategories identified.

and outcome. In the categories patient data, doctor action and nurse action, theory seemed to be integrated with practice; for example, in the category patient data and the subcategory critical assessment findings, a participant had the theoretical knowledge (theory) of the clinical manifestations of a patient that presented with decreased cardiac output which she then related to pulmonary embolism (practice) as a possible cause. The participant described it as follows: 'He had a massive pulmonary embolus ... his pulmonary arteries were totally occluded; in other words, at the end of the day this patient had no cardiac output.'

Regarding some of the other the categories, such as treatment, communication, experience and outcome, the experience was that theory was not integrated into practice. With reference to the category communication and the subcategory patient communication, an incident was described of how a pacemaker accidentally disconnected from a patient and subsequently resulted in a temporary loss of heart beat. Both the participant and the patient experienced the incident as terrifying. The participant stated: 'It was nerve-racking!' The participant stated that she was unable to communicate with the patient. The unit manager intervened and reassured the patient, as revealed by the following reported statement: 'So she told him that it won't happen again, that it can't happen again, that he must try and relax.' The unit manager correctly understood the non-verbal communication of the patient, realised that he was terrified, and therefore reassured him. The participant, however, was so traumatised by what had happened that she was unable to act appropriately - as she stated, 'No, I got stupid'.

\section{Theme 2: Critical analysis of knowledge}

The critical analysis of knowledge is a theme emerging from this study and refers to a process whereby existing knowledge is analysed through a process where the participant challenges assumptions and images. This leads to discovering alternatives and, in this way, new knowledge is generated (Burton 2000:1012). Under this theme, the categories knowledge, doctor or nurse action, medication, theory-practice integration, outcome, experience, student reasoning and malfunctioning of equipment emerged (Table 1). The participants demonstrated the ability to analyse their actions and thoughts, which lead to the clarification of concerns relating to their experiences.

In some categories of this theme, namely knowledge, doctor or nurse action and medication, integration of theory and practice occurred. A participant motivated her interventions regarding medication administration as follows: 'Om vir 
TABLE 2: Strategies used to enhance trustworthiness.

\begin{tabular}{|c|c|c|}
\hline Criteria & Strategies to ensure trustworthiness & Strategies used in this research \\
\hline \multirow[t]{7}{*}{ Truth value (credibility) } & Prolonged engagement & $\begin{array}{l}\text { - Prolonged accompaniment } \\
\text { - Guided reflection }\end{array}$ \\
\hline & Accurate description & - Accurate descriptions \\
\hline & Triangulation & $\begin{array}{l}\text { - Methodological and theoretical triangulation } \\
\text { - Literature control }\end{array}$ \\
\hline & Reflexivity & - Reflective notes \\
\hline & Member checking & - Verbatim transcripts \\
\hline & Structural coherence & - Integration of data in a logical manner \\
\hline & Authority of researcher and referral adequacy & - Familiarity with the critical care nursing field \\
\hline \multirow[t]{2}{*}{ Transferability (applicability) } & Representativeness & - All available participants \\
\hline & Dense description & - Expert checking and consensus \\
\hline \multirow[t]{3}{*}{ Consistency (dependability) } & Dense description & - Dense description of research method \\
\hline & Code-recoding & - Recoding \\
\hline & Triangulation & - Experts on qualitative subject \\
\hline Neutrality (confirmability) & Reflexivity & - Reflective notes \\
\hline
\end{tabular}

Source: Based on Lincoln, Y.S. \& Guba, E.G., 1985, Naturalistic inquiry, Sage, Beverly Hills.

die pasiënt kardiale uitwerp te gee, om 'n bloeddruk te handhaaf sodat ons sy perfussie kan handhaaf' [To give the patient cardiac output, to maintain a blood pressure so that we could maintain his perfusion]. Another participant stated: 'Ek dink, nee ek dink 'n mens kan nooit genoeg weet nie. Mens moet ten alle tye op datum bly met die nuwe medikasie' [I think, no, I think one could never know enough. One should be up to date with new medication at all times]. Both participants were able to apply theory to practice. The latter revealed a selfawareness of a lack of knowledge to care for her patient and a willingness to take responsibility for her own learning. This notion is supported by McBrien (2007:133), who avers that both knowledge and patient care are enhanced by reflection.

However, in the categories outcome, experience, student reasoning and malfunctioning of equipment, theory was not integrated. Regarding the category outcome and the subcategory patient outcomes, the participant was unable to anticipate the outcomes of disconnecting a patient with no prognosis, from a ventilator as is evident from the following statement:

'What is likely to happen? So, to my greatest surprise, within 5 minutes ... I removed it; I disconnected the ... the ventilator from the ET [endo tracheal] tube, put him on T-Piece with about 50\% oxygen. The patient starts desaturating' (Participant 6).

The following statement regarding the same incident in the category experience and the subcategory previous experience illustrates the importance of previous experience in enhancing theory-practice integration as demonstrated by the following statement:

'But what I know, I have nursed a patient on a ventilator; then you wean, to put a patient on a T-piece so that he can breathe on his own for ten minutes' (Participant 6).

Although the participant anticipated a positive outcome of her patient to breathe unassisted, deterioration in the breathing pattern occurred instead. It appeared that the participant used previous theoretical and practical knowledge of weaning an uncomplicated patient from a ventilator to understand the situation, but showed a lack of practical experience and knowledge to predict the outcome of this complicated situation. In this instance, injury to the respiratory centre of the brain would eventually result in inadequate breathing, which the student could not understand. This demonstrates the importance of learning from past experiences because reflection has the ability to enhance knowledge as described by McBrien (2007:133).

In the category student reasoning, the incident described focused on a patient suffering from a massive pulmonary embolus. In this category, theory was not integrated as illustrated by the following statement: 'Moes massief van aard gewees het, want dit het onmiddellik, uhm ... ek het 'n afleiding gemaak, bilateraal die twee hoof brongusse geocclude ...' [Must have been massive, because it immediately uhm ... I draw a conclusion, occluded the two main bronchi bilaterally ...]. The participant used both theoretical knowledge and practical skill in this instance; however, the description was incorrect, because she should have indicated that the blood vessels supplying blood to the bronchi were occluded and not the bronchi themselves. If students were guided through reflection by a clinical expert, misconceptions or misinterpretations could be eliminated, and theorypractice integration would have enhanced. In this instance, the participant was provided with the correct information at the end of the interview. The value of guided reflection by a clinical expert was demonstrated, because incorrect conclusions could be corrected.

\section{Theme 3: Critical analysis of feelings}

This theme contains the affective component of the responses. Rich and Parker (1995:1052) emphasise the importance of analysing positive feelings and removing obstructive feelings to generate new knowledge and to move towards a changed perspective. Two categories - namely experience and expression of feelings - with their subcategories emerged in the theme critical analysis of feelings (Table 1). Theory-practice integration in the theme critical analysis of feelings was not explicit, but rather implicit. Overall, theory 
was not integrated in practice in this theme; for example, the element of trauma featured in the category experience. Most of the incidents the participants described were incidents where the participants were exposed to patients dying or where the patient had a near-death experience. One participant put it simply: 'Then again it was a traumatic experience for me.' Another participant said: 'So, that for me it was really a traumatic experience.' It appeared that the theory of death or a near-dying experience was familiar, but the feelings evoked by these incidents overwhelmed the participants. It is the authors' opinion that the feelings experienced by the participants were normal. However, the repetitive description of trauma and of unresolved feelings could possibly be due to the fact that the participants had no opportunity to be debriefed. It is well-known that debriefing of traumatic incidents could relief uncomfortable feelings (Williams, Dawson \& Kristjanson 2008:88).

A welter of feelings emerged as evident from the subcategories, namely feelings of confusion and frustration, incompetence, loss, denial, anger, acceptance, guilt, feelings towards colleagues and feelings of discrepancy. Theorypractice integration did not occurred in any of the categories and subcategories of the theme critical analysis of feelings; for example, in the subcategory feelings of incompetence. One participant described her feelings of incompetence as follows: 'Because I - I can tell you, like cardio pulmonary resuscitation [CPR], I know it backwards, but come in that situation, it feels like I know nothing.' Bond (2009:136) emphasises that stress and anxiety paralyse students' ability to think creatively and apply complex thought processes, which will therefore impact on their competency level.

A participant described her feelings of confusion and frustration regarding the indecisiveness of doctors as follows: 'Maar as die dokters begin twyfel oor wat hulle doen, dan begin jy ook twyfel as 'n verpleegkundige' [But when the doctors started to be uncertain about what should be done, then you as a nurse also started to doubt]. It appeared that the student knew the theory of what should be done, but in practice she was confronted with powerful factors such as the views of doctors.

In the subcategory guilt, the following statement describes a participant's feeling of guilt concerning the death of a patient: 'Ek weet nie net nie hoe gaan ek van die skuldgevoelens ontslae raak nie, want die pasiënt is toe uiteindelik oorlede' [I don't know how I am going to get rid of these feelings of guilt, because the patient eventually died]. After guided reflection was facilitated, the participant explained her feelings as follows:

'Ek dink dit is goed om terug te gaan deur hierdie metode en duidelikheid te kry oor wat jy kon gedoen het en of dit wel sou gehelp het en klaarheid in jouself te kry en nie aan te hou om jouself te verwyt nie'.

[I think it is good to reflect by making use of this method, and to get clarity on what you could have done and whether it would have helped. It assists one to get clarity and not to keep on blaming oneself (Participant 1).
Guided reflection in this context therefore appeared to be of value to resolve uncomfortable feelings when traumatic incidences occurred.

\section{Theme 4: Changed perspective experienced}

In this study the participants seemed to have experienced a changed perspective regarding several aspects. Mezirow's theory of reflective thinking is based on the idea of a transformed perspective (Wang \& King 2006). A changed or new perspective is described as an integrated, internalised knowledge network and value system (Van Vuuren \& Botes 1999:33). By internalising knowledge, persons could gain a changed perspective on cognitive, psychomotor and affective skills. The categories that emerged from this theme were the following: view of the doctor or nurse action, outcome of action, participants' view on theory-practice integration, knowledge, feelings, reporting and education (Table 1).

Theory seems to be integrated into practice in all the categories, except knowledge. In the category view of doctor- or nurse action and the subcategory agree or disagree, a participant agreed that the doctor's intervention was appropriate as illustrated by the following:

'But he has convinced that beyond, without a doubt. Even if this guy is not brain dead he had, you know, he had practically brain damage. You know, he showed me some of the, of his findings to see that he practically ...' (Participant 7).

This statement followed a situation where, the doctor requested the nurse to disconnect the ventilator, which resulted in the death of the patient. The participant became upset about the situation. The doctor convinced the participant via a practical demonstration of the medical diagnosis of irreversible brain damage. Towards the end of the guided reflective interview the participant acknowledged that the doctor had taken the correct decision, which resolved some questions and uncomfortable feelings regarding the incident. It could therefore be concluded that guided reflection assisted the participant in integrating theory with practice and that she has reached a different perspective on the incident.

In the category knowledge and the subcategory subjectspecific knowledge, theory was not integrated with practice, as illustrated by the following statement:

'How a pacemaker works ... if something happens, what to ... I can't just glance at the monitor or glance at the patient and know which part of it is not working, and what to do in an emergency' (Participant 3).

The participant realised that she lacked the appropriate knowledge to implement her practical skills, but indicated her desire to have the knowledge.

Regarding the category feelings and the subcategory positive feelings, participants experienced guided reflection positively as one participant stated: 'On the whole, the experience of guided reflection was positive. It helped me to realise that I had already started to recognise certain weak spots.' According to Teekman (2000:1133), the value of guided reflection is that 
it brings about personal understanding and self-control and, therefore, self-empowerment. Guided reflection assisted the participants in understanding the source of their feelings, which led to clarity and empowerment to deal with the situation. Critical care nursing students in the research context could experience a changed perspective on nursing and nursing interventions if they understood the reasons for, or the factors that contributed to, their feelings. An understanding of the clinical situation, self-control, and selfempowerment could enhance theory-practice integration.

The participants suggested solutions to the problem of ineffective reporting during staff handover, as illustrated by the following statement in the category reporting, subcategory staff-related reporting: 'Try to get give-over more fully. Um, if they ask questions, slow it down. Everybody's so in a hurry to get away to get home.' The participant realised the need to provide complete information regarding the patient to ensure good nursing care. The theory of proper reporting was transformed into practice.

Regarding the category education, the participants identified their own and the nursing staff's lack of knowledge of pharmacological aspects (theory) recognition of side effects and management of complications in a patient (practice). They suggested possible solutions such as inservice-training, orientation and the utilisation of mentors. Suggesting solutions to problems shows that students were able to evaluate the situations and suggest alternatives whilst developing a changed perspective on the problems they experienced.

It appeared as if guided reflection assisted the participants to get clarity about and to reach a positive outlook on challenging situations, which is illustrated by the following statement:

'The therapeutic effect on me was that I could get rid of the negative feelings and questions of the specific scenarios in an anonymous confidential milieu, which had the value that I could show my true feelings' (Participant 5).

Overall it appeared that the issues described by the participants in the beginning of the guided reflective interviews, assisted almost all of them to reach clarity in some areas. They could revisit and change their perspectives on the described incidents. The core issue is to learn from experience in such a way that cognitive and affective changes may develop (Boyd \& Fayles 1983:100).

From the data it became evident that the participants had gone through a series of cognitive and affective processes. This resulted in a transformed understanding of theory and practice. Critical care nursing students also discovered that incidents in critical care nursing practice evoked a variety of feelings. Guided reflection offered the participants the opportunity to deal with complicated experiences, which resulted in a changed perspective on inter alia theorypractice integration. It follows that guided reflection could be used as a teaching and learning strategy to prepare student nurses to become competent in dealing with the challenges of nursing care in critical care units.

The findings also suggest that the themes that emerged in the course of this study seem to fit into the process of reflection as illustrated in the conceptual framework in Figure 1. This study demonstrates the complexity of theory-practice integration, as well as the inter-relatedness of these two concepts.

\section{Recommendations}

The following recommendations were made concerning nursing education, nursing management and further research. Hospital management, educators, clinical facilitators and trained critical care nurses should be aware of the positive impact of theory-practice integration on the quality of nursing care and the learning environment. They should become acquainted with teaching strategies such as guided reflection. By means of guided reflection, uncomfortable feelings and ethical dilemmas could be resolved and complex thought processes facilitated, which would have a positive impact on quality patient care.

This research could be replicated in other hospitals so as to compare the results. A larger study of this kind, involving the public as well as the private hospital sectors, could be done. A study to refine and simplify the framework of guided reflection used for this study could be carried out in order to make it less time-consuming to implement.

\section{Limitations of the study}

This study was conducted in only one private hospital, which means that the findings will have meaning for this specific context only. Due to time constrains, one guided reflective interview was done per participant. More of these sessions could have generated richer data and even a greater understanding of the value of guided reflection.

\section{Summary}

From the large amount of literature on the theory-practice gap (the inadequate theory-practice integration in student nurses) it is evident that this is a matter of concern (Maben et al. 2006:466). This phenomenon seems to be relevant to both basic as well as post basic nursing programmes. Although different solutions have been proposed to bridge this gap, it appears that there is no single answer to this problem.

It could be said that the stated objectives were met. The researcher facilitated guided reflection in second-year critical care nursing students and described how they experienced the integration of theory and practice when guided reflection was applied, which resulted in a transformed perspective on learning and clinical practice.

\section{Conclusion}

In conclusion, it is recommended that guided reflection should be included as a teaching and learning strategy 
method to enhance theory-practice integration in nursing. All role players, such as nurse educators, professional nurses, mentors and preceptors, would benefit from an awareness of the value of guided reflection not only for patient care but for nurses' self-development as well.

\section{Acknowledgement Competing interest}

There was no conflict of interest in writing this article.

\section{Authors' contributions}

I would like to acknowledge a debt of gratitude to H.S.d.T (University of South Africa) and A.B. (University of South Africa), my study leaders, for their contribution to the writing of this article. A special thanks to Jackie Viljoen, the editor, and Christel de Bruin, the critical reader, for their contributions.

\section{References}

Baxter, P., 2007, 'The Care model of clinical supervision: Bridging the theory-practice gap', Nurse Education in Practice 7, 103-111.http://dx.doi.org/10.1016/j.nepr.2006.06.007, Nurse Education

Billings, D.M. \& Kowalski, K., 2006, 'Bridging the theory-practice gap with evidence-based practice', The Journal of Continuing Education in Nursing 37(6) 248-249. PMid:17144113

Bond, M.E., 2009, 'Exposing shame and its effect on clinical nursing education', Journa of Nursing Education 48(3), 131-140. http://dx.doi.org/10.3928/0148483420090301-02, PMid:19297963

Botha, D.E., 2006, 'Die onderrig van professionele praktyk in die geïntegreerde, vierjaar verpleegkunde program', [The teaching of professional practice in the integrated, four-year nursing programme] PhD Thesis, School of Nursing, University of the Free State.

Boyd, E.M. \& Fayles, A.W., 1983, 'Reflective learning: The key element to learning from experience', Journal of Humanistic Psychology 23(2), 99-117. http://dx.doi. org/10.1177/0022167883232011

Burns, N. \& Grove, S.K., 2005, The practice of nursing research conduct, critique and utilization, 5th edn., Elsevier, St Louis.

Burton, J.A., 2000, 'Reflection: Nursing practice and education panacea?', Journal of Advanced Nursing, 31(5), 1009-1017. http://dx.doi.org/10.1046/j.13652648.2000.01395.x

PMid:10840233

Chapman, N., Dempsey, S.E. \& Warren-Forward, H.M., 2009, 'Workplace diaries promoting reflective practice in radiation therapy', Radiography 15, 166-170. http://dx.doi.org/10.1016/j.radi.2008.04.008

Clark, T. \& Holmes, S., 2007, 'Fit for practice? An exploration of the development of newly qualified nurses using focus groups', International Journal of Nursing Studies
44, 1210-1220. http://dx.doi.org/10.1016/j.ijnurstu.2006.05.010, PMid:16872614

De Vos, A.S., Strydom, H., Fouché, C.B. \& Delport, C.S.L., 2005, Research at grass roots for social sciences and human service professions, 3rd edn., Van Schaik, Pretoria.

Duffy, A., 2008, 'Guided reflection: A discussion of the essential components', British Journal of Nursing 17(5), 334-339. PMid:18414299

Duffy, A., 2009, 'Guiding students through reflective practice - The preceptors experiences, A qualitative descriptive study', Nurse Education in Practice 9, 166175. http://dx.doi.org/10.1016/j.nepr.2008.07.002, PMid:18768370
Foster, J. \& Greenwood, J., 1998, 'Reflection: A challenging innovation for nurses', Contemporary Nurse 7(4), 165-172. http://dx.doi.org/10.5172/conu.1998.7.4.165, PMid:10095497

Gallagher, P., 2004, 'How the metaphor of a gap between theory and practice has influenced nursing education', Nurse Education Today 24, 263-268. http://dx.doi. org/10.1016/j.nedt.2004.01.006, PMid:15110435

Gray, D.E., 2009, Doing research in the real world, 2nd edn., Sage, Los Angeles .

Gregory, D., Guse, L., Davidson, D., Davis, P. \& Russell, C.K., 2009, 'What clinical learning contracts reveal about nursing education and patient safety', Canadian Nurse 10(8), 20-25.

Johns, C., 1995, 'Framing learning through reflection within Caper's fundamental ways of knowing', Journal of Advanced Nursing 22(1), 226-234. http://dx.doi. org/10.1046/j.1365-2648.1995.22020226.x, PMid:7593941

Jones, J.H. \& Treiber, L., 2010, 'When the 5 rights go wrong medication errors from the nursing perspective', Nursing Care Quality 25(3), 240-247. http://dx.doi. org/10.1097/NCQ.0b013e3181d5b948, PMid:20164807

Jones, W.S., Hanson, J.L. \& Longacre, J.L., 2004, 'An intentional modelling process to teach professional behaviour: students' clinical observation of preceptors', Teaching and Learning in Medicine 6(3), 264-269. http://dx.doi.org/10.1207/s15328015t/m1603_8, PMid:15388383

Landers,M.G.,2000, 'Thetheory-practicegapinnursing:Theroleofthenurseteacher', Journalof AdvancedNursing32(6),1550-56.http://dx.doi.org/10.1046/j.1365-2648.2000.01605.x PMid: 11136425

Lerners, D.W. \& Piccone, A.V., 2006, 'Tracking the development professional values in undergraduate nursing students', Journal of Nursing Education 45(12), 504-511. PMid:17190363

Lincoln, Y.S. \& Guba, E.G., 1985, Naturalistic inquiry, Sage, Beverly Hills.

Maben, J., Latter, S. \& Macleod Clark, J.M., 2006, 'The theory-practice gap: Impact of professional-bureaucratic work conflict on newly-qualified nurses', Journal of Advanced Nursing 55(4), 465-477. http://dx.doi.org/10.1111/j.13652648.2006.03939.x, PMid:16866842

Mabuda, B.T., Potgieter, E \& Alberts, U.U., 2008, 'Student nurses' experiences during clinical practice in the Limpopo Province', Curationis 19-27. PMid:18592945

Malesela, J.M.L., 2009, 'Case study as a learning opportunity among nursing students in a university', Health SA Gesondheid 14(1), Art. \#434, viewed 29 July 2010 from http://www.hsag.co.za

McBrien, B., 2007, 'Learning from practice: Reflections on a critical incident', Accident and Emergency Nursing 15, 128-133. http://dx.doi.org/10.1016/j. aaen.2007.03.004, PMid:17540574

Morgan, R., 2006, 'Using clinical skills laboratories to promote theory-practice integration during first practice placement: An Irish perspective', Journal of Clinical Nursing 15,
155-160. http://dx.doi.org/10.1111/j.1365-2702.2006.01237.x, PMid:16422732

Rafferty, A.M., Allcock, N. \& Lathlean, J., 1996, "The theory/practice "gap": Taking issue with the issue', Journal of Advanced Nursing 23(4), 685-691. http://dx.doi. org/10.1111/j.1365-2648.1996.tb00038.x, PMid:8675884

Rich, A. \& Parker, D.L., 1995, 'Reflection and critical incident analysis: Ethical and moral implications of their use within nursing and midwifery education', Journal of Advanced Nursing 22(6), 1050-1057. http://dx.doi.org/10.1111/j.1365-2648.1995.tb03104.x

Schmidt, N.A. \& Brown. J.M., 2009, Evidence-based practice for nurses' appraisal and application of research, Jones \& Barlett, Boston.

Streubert Speziale, H.J. \& Carpenter, D.R., 2007, Qualitative research in nursing advancing the humanistic approach, 4th edn., Lippincott Williams \& Wilkins, advancing the
Philadelphia.

Sedgwick,M.G.\&Yonge,O.,2008, 'Undergraduatenursingstudents'preparednessto "gorural”, Nurse Education Today 28, 620-626. http://dx.doi.org/10.1016/j.nedt.2007.09.014, P Mid:18031871

Teekman, B., 2000, 'Exploring reflective thinking in nursing', Journal of Advanced Nursing 312(50), 1125-1135. http://dx.doi.org/10.1046/j.1365-2648.2000.01424.x, PMid:10840246

Van Vuuren, M. \& Botes, A., 1999, 'Konsep analise van reflektiewe denke', Curationis 22(9), 25-35. PMid:11040626

Wang, V.C.X. \& King, K.P. 2006, 'Understanding Mezirow's theory of reflectivity from Confucian perspectives: a model and perspective', Radical pedagogy, viewed 16 September 2011 from http://radicalpedagogy.icaap.org/content/issue8_1/wang. Sept
html

Williams, A.M., Dawson, S.S. \& Kristjanson, L.J., 2008, 'Translating theory into practice: Using action research to introduce a coordinated approach to emotional care', Patient Education and Counselling 73, 82-90. http://dx.doi.org/10.1016/j. pec.2008.04.011, PMid:18562150 